\title{
Futures Markets and the Fluctuations in Inflation, Monetary Growth, and Asset Returns
}

\section{Citation}

Barro, Robert J. 1986. Futures markets and the fluctuations in inflation, monetary growth, and asset returns. Journal of Business 59(S2): 21-38.

\section{Published Version}

doi:10.1086/296337

\section{Permanent link}

http://nrs.harvard.edu/urn-3:HUL.InstRepos:3475682

\section{Terms of Use}

This article was downloaded from Harvard University's DASH repository, and is made available under the terms and conditions applicable to Other Posted Material, as set forth at http:// nrs.harvard.edu/urn-3:HUL.InstRepos:dash.current.terms-of-use\#LAA

\section{Share Your Story}

The Harvard community has made this article openly available.

Please share how this access benefits you. Submit a story.

Accessibility 


\section{Futures Markets and the}

Fluctuations in Inflation, Monetary Growth, and Asset Returns*

\section{Introduction and Outline of the Analysis}

The U.S. dollar is extremely useful as a means of payment and a unit of account. This convenience motivates people to use the dollar as a basis for spot agreements as well as for long-term contracts. But if inflation is uncertain, then there are risks associated with the specification of obligations in terms of dollars. These risks, which have been substantial in recent years, affect the equilibrium interest rates on financial assets and the required expected returns from physical investments. In particular, to the extent that people lack information about future price levels, they will find it risky to undertake long-term projects. Hence, uncertainty about inflation tends to retard investment and to distort the allocation of resources across sectors of the economy.

Futures contracts in price indices would alleviate some of the adverse consequences from inflation. First, the existence of these futures markets would provide a convenient means for people to hedge the risks from inflation. In particular, an investor in a long-term project would not also have to be a speculator on inflation. Second, the price quotes on these markets would be a useful source of information, which would allow people to calculate accurately the real value of their dollar-denominated contracts.

* I am grateful for helpful comments from Sandy Grossman, Frank Rose, and Roger Rutz.

(Journal of Business, 1986, vol. 59, no. 2, pt. 2)

(C) 1986 by The University of Chicago. All rights reserved. 0021-9398/86/5902-0012\$01.50
Inflation and nominal interest rates have been volatile in recent years. Futures contracts in price indices would help in this environment by enhancing information about prices and by providing a convenient means for people to hedge against inflation. There is some evidence that the availability of these instruments would encourage investment and reduce the mean real rate of return on long-term bonds. Indexed bonds-which are now significant in Britainserve a similar purpose. In the absence of such bonds, there would be a market for price-index futures, although the volume of trading would probably be modest. 
This study analyzes the role of price-index futures in an environment of volatile inflation and interest rates. Section II discusses the predictability of inflation in the U.S. economy. Notably, there is evidence that inflation uncertainty is substantial and has increased since the early 1970 s. Section III relates the uncertainty of inflation to the observed volatility in nominal interest rates. One conclusion is that the volatility in interest rates has dramatically increased the risk from holding dollardenominated long-term bonds. This extra risk explains the substantial recent interest in long-term interest rates relative to short-term rates.

Section IV analyzes how the introduction of price-index futures would affect equilibrium real interest rates. There is also a discussion of the beneficial effects of this futures market on investment. Finally, by looking at the net position of various sectors in nominally denominated assets and liabilities, there is some indication of the sources of hedging demand for consumer price index (CPI) futures. Nonfinancial businesses, insurance companies, pension funds, and households are potential participants, whereas a variety of financial institutions would seem to be more interested in interest-rate futures.

Section $\mathrm{V}$ points out that futures contracts on price indices are analogous to index bonds. Thus it is useful to study the recent experience of the United Kingdom with indexed financial instruments. That experiment shows a significant level of demand, especially from pension funds. However, there is a limited volume of trading in these assets.

Sections VI and VII document some of the adverse effects from uncertain inflation and from the underlying behavior of monetary policy. Specifically, the unpredictability of aggregate money and prices tends to go along with greater dispersion of actual and expected inflation across markets. This dispersion leads in turn to adverse effects on such macroeconomic variables as output, employment, and investment. The results suggest that the implementation of a futures market in price indices (or a market in indexed bonds) would have beneficial effects on these macro variables.

Finally, Section VIII considers some general criticisms of futures markets. There is no evidence that these markets divert capital from productive enterprises; rather, the indication is that futures markets foster information flows and thereby improve the allocation of resources. Similarly, the positive association between price volatility and the volume of futures trading reflects reverse causation. More price volatility motivates an increase in the extent of futures trading, which then has some moderating influence on price volatility.

\section{The Predictability of Inflation}

When people enter into contracts that fix obligations in nominal terms, a change in the price level alters the real value of these obligations. For 
example, the real value of a nominally denominated bond is affected by inflation. To the extent that inflation is predictable, the fixing of contracts in terms of dollars has no major economic consequences. Each party to the agreement would base his or her decision on the known real costs or benefits. In the case of bonds, people would know ex ante the real rate of interest-that is, the nominal rate less the rate of inflation-which then affects decisions to save and invest. However, to the extent that inflation is unpredictable, the real value of obligations will be uncertain. In order to see how important this element is, I examine first the degree to which U.S. inflation has been predictable.

Fama and others ${ }^{1}$ have measured the information that interest rates and other variables contain about future inflation. Table 1 shows the general nature of these types of results for regression equations with annual data from the post-World War II period. For 1953-71, the interest rate (on government issues with 1-year maturity) has roughly a one-to-one relation to subsequent inflation (based on the CPI without the shelter component). The coefficient of the interest rate in row 1 of the table is $.82(\mathrm{SE}=.15)$. Adding lagged values of inflation and monetary growth (M1) in row 2 eliminates the interest rate as a significant variable (contrary to Fama). This finding indicates that there are systematic variations over time in expected real interest rates. The standard-error-of-estimate in row 2 is $\hat{\sigma}=0.9 \%$, which suggests a relatively low forecast error for 1-year-ahead inflation.

After 1971 the interest rate is not useful as a predictor of inflation (rows 5 and 6 of the table). Also, even with the lags of inflation and monetary growth included, the error variance for inflation is greater than before $(\hat{\sigma}=.015$, versus the earlier value of .009$)$. Thus two points emerge from these results. First, in recent years market interest rates are not helpful for predicting inflation, and, second, using other variables such as lagged inflation and monetary growth, the prediction error for inflation is substantially higher than it used to be. Thus, because of the substantial uncertainty about inflation, market participants would have serious problems in evaluating the real implications of nominally denominated contracts, including dollar bonds.

The Livingston survey on inflationary expectations provides some related information. This semiannual survey, begun in 1946, asks roughly fifty economists (fewer in the early years of the sample) about their projected value of the CPI 6 or 12 months hence. Presumably, these forecasts consider the variables, such as nominal interest rates, that appear in table 1. The implied forecasts of inflation for each year, denoted $\pi_{t}^{e}$, are shown along with actual inflation for 1948-84 in table 2. (The value $\pi_{t}^{e}$ comes from the two 6-month-ahead forecasts for year $t$.) For $1953-71$, the mean value of expected inflation is $0.9 \%$ per year,

1. Fama 1975; Schwert and Nelson 1977; and Fama and Gibbons 1982. 


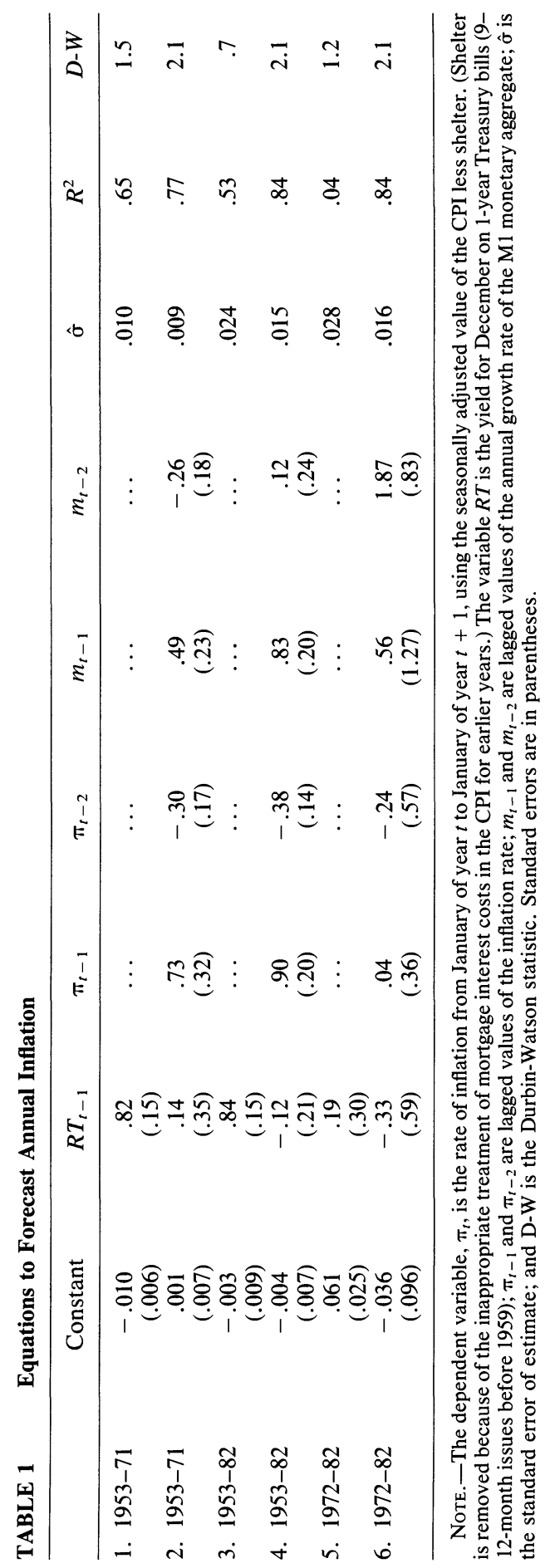


TABLE 2 Inflation Rates and Expected Inflation from the Livingston Survey (\% per year)

\begin{tabular}{|c|c|c|c|}
\hline Year & $\pi_{t}$ & $\pi_{t}^{e}$ & $\pi_{t}-\pi_{t}^{e}$ \\
\hline $\begin{array}{l}1948 \\
1949\end{array}$ & $\begin{array}{r}.8 \\
-3.0\end{array}$ & $\begin{array}{r}1.2 \\
-4.0\end{array}$ & $\begin{array}{r}-.4 \\
1.0\end{array}$ \\
\hline $\begin{array}{l}1950 \\
1951 \\
1952 \\
1953 \\
1954\end{array}$ & $\begin{array}{r}8.2 \\
4.1 \\
.2 \\
.7 \\
-1.2\end{array}$ & $\begin{array}{r}-.2 \\
3.1 \\
1.1 \\
-.6 \\
-.9\end{array}$ & $\begin{array}{r}8.4 \\
1.0 \\
-.9 \\
1.3 \\
-.3\end{array}$ \\
\hline $\begin{array}{l}1955 \\
1956 \\
1957 \\
1958 \\
1959\end{array}$ & $\begin{array}{r}.0 \\
3.3 \\
3.4 \\
1.3 \\
1.1\end{array}$ & $\begin{array}{r}.3 \\
.5 \\
1.3 \\
.1 \\
.6\end{array}$ & $\begin{array}{r}-.3 \\
2.8 \\
2.1 \\
1.2 \\
.5\end{array}$ \\
\hline $\begin{array}{l}1960 \\
1961 \\
1962 \\
1963 \\
1964\end{array}$ & $\begin{array}{r}1.6 \\
.7 \\
1.4 \\
1.5 \\
1.0\end{array}$ & $\begin{array}{r}.7 \\
.6 \\
1.0 \\
1.0 \\
1.0\end{array}$ & $\begin{array}{l}.9 \\
.1 \\
.4 \\
.5 \\
.0\end{array}$ \\
\hline $\begin{array}{l}1965 \\
1966 \\
1967 \\
1968 \\
1969\end{array}$ & $\begin{array}{l}2.0 \\
3.0 \\
3.5 \\
4.0 \\
5.3\end{array}$ & $\begin{array}{l}1.1 \\
1.7 \\
2.1 \\
2.8 \\
2.9\end{array}$ & $\begin{array}{r}.9 \\
1.3 \\
1.4 \\
1.2 \\
2.4\end{array}$ \\
\hline $\begin{array}{l}1970 \\
1971 \\
1972 \\
1973 \\
1974\end{array}$ & $\begin{array}{r}4.4 \\
3.3 \\
3.6 \\
9.5 \\
11.2\end{array}$ & $\begin{array}{l}3.6 \\
3.8 \\
3.3 \\
3.6 \\
6.2\end{array}$ & $\begin{array}{r}.8 \\
-.5 \\
.3 \\
5.9 \\
5.0\end{array}$ \\
\hline $\begin{array}{l}1975 \\
1976 \\
1977 \\
1978 \\
1979\end{array}$ & $\begin{array}{r}6.5 \\
5.2 \\
6.0 \\
8.2 \\
11.3\end{array}$ & $\begin{array}{l}6.7 \\
5.6 \\
5.6 \\
6.2 \\
7.6\end{array}$ & $\begin{array}{r}-.2 \\
-.4 \\
.4 \\
2.0 \\
3.7\end{array}$ \\
\hline $\begin{array}{l}1980 \\
1981 \\
1982 \\
1983 \\
1984\end{array}$ & $\begin{array}{r}10.3 \\
7.7 \\
4.1 \\
4.0 \\
3.1\end{array}$ & $\begin{array}{r}10.4 \\
9.7 \\
6.1 \\
4.5 \\
5.3\end{array}$ & $\begin{array}{r}-.1 \\
-2.0 \\
-2.0 \\
-.5 \\
-2.2\end{array}$ \\
\hline
\end{tabular}

NoTE. - The inflation rate, $\pi_{t}$, refers to the change in the CPI from January of each year to January of the next year. I use the figures that exclude the shelter component in order to avoid some problems of measuring mortgage interest costs. The variable $\pi_{t}^{e}$, from the Livingston Survey, comes from the Federal Reserve Bank of Philadelphia. I use an average for each year of the 6-month forecasts (from December of the previous year and June of the current year). 
while the mean of the standard deviation of the survey responses across the participants is $0.6 \%$. For $1973-85$, the mean of expected inflation is $6.1 \%$ with a mean standard deviation of $1.7 \%$. The tripling in the average standard deviation-from $0.6 \%$ to $1.7 \%$-indicates that greater differences of opinion about future inflation have accompanied the increased forecasting variance for inflation (as well as the rise in mean inflation). Although this association is not inevitable, it is to be expected that greater overall volatility of inflation would go along with a greater diversity of opinion. Thus the Livingston data reinforce the conclusion that problems with forecasting future prices have become much more serious in recent years.

\section{Inflation Risk and Asset Returns}

The recent volatility of inflation has been associated with a great increase in the volatility of nominal interest rates. Table 3 (based on Ibbotson and Sinquefield [1985]) shows the standard deviations of monthly returns on various assets from 1926 to 1984. In each case, the standard deviation (expressed on an annual basis) is relative to the asset's average return for the year. For example, on long-term government bonds the standard deviation for nominal returns in 1981 was a remarkable 21 percentage points per year, as compared with a mean nominal return during that year from holding bonds of about $2 \%$ per year. By contrast, the standard deviation was typically below 5 percentage points per year until the late 1960s and did not get much above 10 percentage points until 1980. Even for Treasury bills, which people often think of as nearly risk free, the standard deviation for monthly returns in 1980 was nearly 1 percentage point per year, as compared with a typical value of about 0.1 percentage point before the late 1960s. When looking at weekly returns on Treasury bills in the recent period, Cornell $(1983 b$, p. 650) finds a particularly dramatic effect. From January 1978 to October 1979, the standard deviation of the weekly returns was about 10 basis points. But from October 1979 to December 1981 this figure rose to about 40 basis points.

The increased volatility of nominal interest rates can have an important effect on the required average real rate of return on nominally denominated assets. Note first that an increase in the short-term rate of interest tends to lower the price of long-term bonds. Thereby, the yield on long-term bonds remains competitive with the new higher yield on short bonds. Further, these effects are particularly strong if the increase in current short-term interest rates signals that future short-term rates are also likely to be higher. This connection arises if either higher inflation or higher real interest rates tend to persist over time. Then a surprise increase in short-term interest rates-due either to higher expected inflation or to higher real rates-tends to go along with low (perhaps negative) realized returns on holdings of long-term bonds. 
The effect on the risk premium on bonds depends on whether increases in nominal interest rates-for example, those due to unexpected inflation - tend to go along with good or bad economic times. If with good times, then bonds do badly in good times and vice versa, which is a desirable property that is consistent with a low mean real rate of return on bonds. But if unexpected increases in nominal interest rates correlate with bad times, then bonds would require a risk premium. Further, given this last pattern of correlation, a greater volatility of interest rates means a larger risk premium.

The standard view until the early 1970s was that high unexpected inflation went along with an economic boom. This association arises in some "Phillips Curve" theories, in which monetary expansions (or some other shocks to aggregate demand) raise both output and prices. But "supply shocks," such as the recent oil crises, tend to lower output while raising the price level. Further, as discussed by Friedman (1977) and documented statistically by Fair (1979, table 3), this type of shock has been dominant in the last decade. Hence, in the present environment, the real return on dollar-denominated assets tends to be good in good times (when inflation is low and output is high) and bad in bad times. This pattern means that these assets now require a risk premium.

Bodie, Kane, and McDonald (1983) have tested part of this hypothesis by observing the covariance between returns on bonds and returns on stocks. They show that the recent rise in yields on long-term bonds can be attributed to the volatility of their real returns. Until 1977 they estimate the premium of long-term bonds over short-term bonds to be near zero. But the recent volatility of interest rates has made long-term bonds so risky that the required excess return rose to about 4 percentage points per year in 1980-82.

It should be possible to estimate the risk premium on bonds by observing the covariance of the real returns with a direct measure of well-being, such as the growth of consumption per person. So far I have been unsuccessful in pinning down this covariance, using monthly or quarterly date since 1977. It may be that the monthly data are insufficiently accurate and that there are not enough quarterly observations (since 1977) to get precise estimates.

\section{Consequences from the Introduction of CPI Futures}

The previous discussion indicates that a holder of a nominal bond will require an inflation risk premium if his or her welfare is low in the same states of nature that inflation is surprisingly high. If this person's welfare is low when there is high inflation only because he or she is a net holder of nominal assets, then the existence of CPI futures will permit this person to eliminate the effect of inflation on his or her well-being. To the extent that a person can perfectly insulate well-being (i.e., real 
TABLE 3 Standard Deviations of Returns on Various Assets

\begin{tabular}{|c|c|c|c|c|c|c|}
\hline Year & $\begin{array}{c}\text { Common } \\
\text { Stocks }\end{array}$ & $\begin{array}{l}\text { Long- } \\
\text { Term } \\
\text { Corporate } \\
\text { Bonds }\end{array}$ & $\begin{array}{l}\text { Long- } \\
\text { Term } \\
\text { Government } \\
\text { Bonds }\end{array}$ & $\begin{array}{l}\text { U.S. } \\
\text { Treasury } \\
\text { Bills }\end{array}$ & $\begin{array}{c}\text { Consumer } \\
\text { Price } \\
\text { Index }\end{array}$ & $\begin{array}{c}\text { Inflation } \\
\text { Adjusted } \\
\text { U.S. Treasury } \\
\text { Bills }\end{array}$ \\
\hline 1926 & 11.74 & .90 & 1.76 & .31 & 2.05 & 2.06 \\
\hline 1927 & 13.22 & 1.39 & 2.66 & .11 & 2.83 & 2.79 \\
\hline 1928 & 17.35 & 1.82 & 3.21 & .59 & 1.73 & 1.78 \\
\hline 1929 & 31.02 & 2.35 & 6.52 & .20 & 1.62 & 1.56 \\
\hline 1930 & 26.26 & 2.21 & 2.25 & .29 & 2.15 & 2.27 \\
\hline 1931 & 43.94 & 6.00 & 5.49 & .16 & 1.48 & 1.98 \\
\hline 1932 & 68.02 & 7.00 & 10.31 & .29 & 1.93 & 1.69 \\
\hline 1933 & 56.07 & 10.65 & 5.11 & .10 & 4.21 & 3.84 \\
\hline 1934 & 22.22 & 2.75 & 4.12 & .04 & 1.99 & 2.38 \\
\hline 1935 & 16.33 & 2.32 & 2.76 & .01 & 2.12 & 1.63 \\
\hline 1936 & 14.40 & 1.11 & 2.10 & .02 & 1.54 & 1.64 \\
\hline 1937 & 23.36 & 1.94 & 5.02 & .05 & 1.69 & 2.24 \\
\hline 1938 & 41.19 & 2.26 & 2.23 & .07 & 1.83 & 1.36 \\
\hline 1939 & 29.51 & 5.16 & 8.11 & .02 & 2.27 & 2.23 \\
\hline 1940 & 26.70 & 1.96 & 4.92 & .02 & 1.08 & 1.03 \\
\hline 1941 & 14.30 & 1.63 & 3.67 & .03 & 2.11 & 1.98 \\
\hline 1942 & 14.71 & .71 & 1.38 & .03 & 1.28 & 1.33 \\
\hline 1943 & 15.62 & .88 & .64 & .01 & 2.29 & 2.32 \\
\hline 1944 & 7.86 & 1.28 & .36 & .01 & .95 & .89 \\
\hline 1945 & 13.13 & 1.37 & 2.70 & .01 & 1.29 & 1.29 \\
\hline 1946 & 18.70 & 2.12 & 2.74 & .00 & 5.70 & 5.69 \\
\hline 1947 & 9.59 & 2.18 & 2.93 & .07 & 3.09 & 2.98 \\
\hline 1948 & 19.94 & 2.12 & 1.90 & .07 & 2.83 & 2.62 \\
\hline 1949 & 10.19 & 2.10 & 1.72 & .02 & 1.66 & 1.67 \\
\hline 1950 & 10.79 & 1.05 & 1.45 & .03 & 1.72 & 1.73 \\
\hline 1951 & 12.23 & 4.02 & 3.14 & .05 & 1.70 & 1.26 \\
\hline 1952 & 11.32 & 2.76 & 3.20 & .07 & 1.14 & 1.18 \\
\hline 1953 & 9.35 & 5.35 & 4.99 & .10 & 1.00 & .90 \\
\hline 1954 & 12.95 & 2.24 & 3.25 & .06 & .74 & .71 \\
\hline 1955 & 12.41 & 2.16 & 3.64 & .13 & .67 & .74 \\
\hline 1956 & 14.76 & 3.20 & 4.50 & .10 & 1.05 & .94 \\
\hline 1957 & 12.62 & 8.66 & 7.71 & .07 & .65 & .71 \\
\hline 1958 & 6.27 & 4.65 & 6.64 & .26 & .88 & .83 \\
\hline 1959 & 8.00 & 3.94 & 3.31 & .17 & .64 & .67 \\
\hline 1960 & 13.42 & 3.63 & 5.72 & .26 & .70 & .71 \\
\hline 1961 & 8.92 & 3.47 & 3.51 & .07 & .51 & .51 \\
\hline 1962 & 20.09 & 2.12 & 3.48 & .08 & .66 & .68 \\
\hline 1963 & 9.81 & 1.23 & .71 & .08 & .54 & .55 \\
\hline 1964 & 4.02 & 1.40 & .88 & .06 & .40 & .39 \\
\hline 1965 & 8.54 & 1.96 & 1.50 & .08 & .65 & .66 \\
\hline 1966 & 10.89 & 4.79 & 7.78 & .11 & .69 & .75 \\
\hline 1967 & 12.11 & 7.65 & 7.16 & .15 & .43 & .39 \\
\hline 1968 & 13.02 & 7.20 & 7.92 & .09 & .40 & .45 \\
\hline 1969 & 12.98 & 7.46 & 10.36 & .20 & .59 & .63 \\
\hline 1970 & 20.29 & 9.61 & 13.42 & .21 & .42 & .49 \\
\hline 1971 & 13.67 & 10.04 & 9.47 & .18 & .55 & .60 \\
\hline 1972 & 6.63 & 3.01 & 5.55 & .16 & .40 & .38 \\
\hline 1973 & 13.87 & 7.46 & 8.19 & .34 & 1.42 & 1.35 \\
\hline 1974 & 23.93 & 11.68 & 8.28 & .34 & .82 & .94 \\
\hline
\end{tabular}


TABLE 3 (Continued)

\begin{tabular}{lcccccc}
\hline Year & $\begin{array}{c}\text { Common } \\
\text { Stocks }\end{array}$ & $\begin{array}{c}\text { Long- } \\
\text { Corporate } \\
\text { Bonds }\end{array}$ & $\begin{array}{c}\text { Long- } \\
\text { Term } \\
\text { Government } \\
\text { Bonds }\end{array}$ & $\begin{array}{c}\text { U.S. } \\
\text { Treasury } \\
\text { Bills }\end{array}$ & $\begin{array}{c}\text { Consumer } \\
\text { Price } \\
\text { Index }\end{array}$ & $\begin{array}{c}\text { Inflation } \\
\text { Adjusted } \\
\text { U.S. Treasury } \\
\text { Bills }\end{array}$ \\
\hline 1975 & 17.89 & 10.07 & 8.38 & .20 & .73 & .82 \\
1976 & 13.72 & 4.44 & 4.71 & .13 & .46 & .39 \\
1977 & 9.55 & 4.50 & 5.54 & .18 & .73 & .88 \\
1978 & 16.64 & 4.45 & 4.46 & .33 & .61 & .80 \\
1979 & 12.80 & 10.31 & 10.43 & .25 & .45 & .59 \\
1980 & 17.53 & 19.91 & 20.42 & .85 & 1.25 & 1.16 \\
1981 & 12.34 & 19.85 & 21.21 & .43 & 1.02 & .92 \\
1982 & 18.32 & 11.94 & 10.07 & .68 & 1.52 & 1.28 \\
1983 & 9.50 & 10.69 & 10.85 & .17 & .68 & .62 \\
1984 & 13.42 & 12.35 & 11.05 & .29 & .57 & .56 \\
\hline
\end{tabular}

SouRCE.-Ibbotson and Sinquefield 1985, p. 52.

consumption) from inflation, he or she will no longer require a risk premium on nominal bonds in order to hold them. That is, the covariance between real consumption changes and the real return on bonds (short or long term) can be reduced to zero because this covariance depends only on the covariance between inflation and consumption changes. The latter will be zero when the person uses CPI futures to insulate completely his or her consumption changes from inflation risk. If this person is the marginal person holding, say, Treasury bills, then it follows that the real yield on bills will fall because of the introduction of CPI futures. Even stronger effects can operate on long-term interest rates. However, it is unclear at this point whether the "marginal person" - in the sense of the person relevant for determination of interest rates-is net long or short on nominally denominated assets.

As indicated before, a person will be hurt by inflation if he or she is a net holder of nominal assets - that is, if the assets with payoffs fixed in dollars exceed the liabilities. Note that for every person with a net credit position there is someone with a net debt position (at least if we include foreigners and the government in the calculations). Thus there will always be balancing gains and losses from unanticipated inflation. However, when people engage in nominally denominated contracts, the randomness of future inflation creates risk because no one knows in advance whether inflation will be higher or lower than anticipated and thus whether he or she will end up realizing gains or losses. This risk has adverse effects on the economic activities, especially long-term investments, in which people are willing to engage. Since CPI futures would eliminate the risks of inflation, they would also spur the types of economic activities that otherwise entail these risks. For example, Milton and Rose Friedman (1984, p. 104) argue that "futures markets 
in price indexes seem to us the single private-market development that will do the most to reduce the harm from uncertain and unstable inflation. They will provide a mechanism that will enable long-range projects to be undertaken despite the uncertainty of inflation, that will enable ordinary people to protect their assets despite that uncertainty."

In order to see how important this type of effect is likely to be, I made a rough estimate of the extent to which various broad groups of the population were holders of net nominal assets or net nominal liabilities. The results appear in table 4, which is based on the Federal Reserve's Flow-of-Funds Accounts for December 1981. At the highest level of aggregation, the households and life insurance/pension funds were net holders of nominal assets to the extent of $\$ 1.84$ trillion. The nominal debtors were the federal government ( $\$ 710$ billion), state and local governments ( $\$ 120$ billion), and nonfinancial business ( $\$ 1.02$ trillion). Various financial intermediaries had a nearly balanced position with respect to nominal assets and liabilities. In this category are commercial banks, savings and loan associations, mutual saving banks, credit unions, finance companies, and money-market funds. However, these institutions tend to be imbalanced with respect to the term structure of nominal interest rates since their assets are typically long-term relative to their liabilities.

Table 4 misses some nominal assets and liabilities in the form of wage agreements and other promised payments for materials. Also, the level of aggregation is too high to pick out individual firms or households whose positions differ from the aggregate of their sectors. For

\begin{tabular}{lr} 
TABLE 4 & $\begin{array}{l}\text { Net Position of Various Sectors for } \\
\text { Nominally Fixed Assets and Liabilities }\end{array}$ \\
\hline Creditor: & 930 \\
Households & 910 \\
Insurance companies and pension funds* & \\
Financial intermediaries (commercial & \\
$\quad$ banks, S\&Ls, mutual savings banks, & \\
credit unions, finance companies, & \\
$\quad$ money-market funds) & $0 \dagger$ \\
Debtor: & 710 \\
U.S. government & 120 \\
State and local government & 1,020 \\
Nonfinancial business
\end{tabular}

SoURCE. - Data are constructed from Board of Governors, Federal Reserve System (1981), table 48, Flow-of-Funds Accounts. Note.-Amounts in \$ billion on December 31, 1981.

* I do not count insurance and pension reserves as nominal liabilities for the companies or as nominal assets for households. Otherwise, the net nominal assets of the insurance companies and pension funds ( $\$ 910$ billion) would be counted as another net nominal asset of the households.

$\dagger$ Roughly. 
example, some researchers argue that unexpected inflation differentially affects old and young persons (see Michael 1979). But table 4 does suggest where some broad groups of the population would fall in terms of their desires to hedge against uncertain movements in the price level. Notably, insurance companies, pension funds, and some members of the household sector would be most eager for protection against unexpectedly high prices. Governments and nonfinancial businesses tend to be on the opposite side. On the other hand, financial intermediaries would be concerned mostly with insurance against shifts in interest rates-especially against increases in long-term rates. Therefore, they would be interested more in interest-rate futures than in CPI futures. However, interest-rate futures would not work for the groups that are imbalanced between nominal assets and liabilities. These groups desire protection against unexpected changes in price levels. Interest-rate futures do not serve this purpose because (surprise) shifts in nominal interest rates (which reflect revisions to expected inflation and to ex ante real interest rates) are not closely correlated with unexpected inflation.

\section{Consumer Price Index Futures and Indexed Bonds}

Given the lack of real-world experience with futures contracts based on the CPI or other price indices, theoretical arguments about the potential demand for these instruments cannot be very convincing. However, futures markets in price indices are essentially equivalent to indexed bonds. These bonds-which adjust the payments of nominal interest and principal in accordance with realized changes in a specified price index-provide for a contractual real rate of interest. Thus, by holding an indexed bond, a person accomplishes the equivalent of a nominal bond plus the appropriate hedge position in a price-index future. It follows that the observed demand for indexed bonds reveals the potential demand for futures contracts in price indices.

Recent experience with indexed bonds falls into three categories: ${ }^{2}$ first, countries such as France (1952-58) and Finland (1945-67) that issued index-linked debt in conjunction with programs of economic stabilization after World War II; second, countries such as Brazil, Argentina, and Israel that exhibit persistently high inflation; and third, the recent experiment in the United Kingdom. For purposes of comparison with the present-day United States, it seems clear that the experience in the United Kingdom would be the most informative.

The British government began in 1975 to issue nontradable "national savings contracts" that were linked in nominal terms to an index of retail prices. Then, following the success of these issues, the govern-

2. For further discussion, see Page and Trollope (1974). 
ment began in March 1981 to issue marketable, long-term bonds ("gilts"). These assets linked the nominal interest payments and principal to a broad index of retail prices. ${ }^{3}$ Until March 1982, purchases of index-linked gilts were restricted to pension funds. Subsequently, they have been available to all, although pension funds are still the major holders.

The initial issue of index-linked bonds in March 1981 provided a real yield of about $2 \% .{ }^{4}$ After averaging $2.8 \%$ in 1982 and $2.9 \%$ in 1983 , the real yield on bonds with maturities of about 25 years rose to $3.4 \%$ in 1984. For January-May 1985 the average yield was 3.5\%. For bonds with a 5-year maturity, the real yield in early 1985 was about $4.5 \%$. This shape for the term structure indicates that the market expects real rates to fall in the future. The pattern of increase in real interest rates from 1981 to 1985 corresponds roughly to that in the United States-in fact, given an international capital market, the observed real interest rates on index-linked bonds in the United Kingtom tell us something about the implicit expected real yields on long-term U.S. government bonds. ${ }^{5}$ That is, the British data on real interest rates may enable us to infer expected rates of inflation in the United States.

As for quantities, the amount of index-linked gilts issued in the United Kingdom from March 1981 through June 1985 was $£ 9.0$ billion in market value, which is $22 \%$ of the public sector borrowing requirement over that period. In terms of the total stock of marketable government bonds outstanding, the index-linked gilts accounted for about $8 \%$ in June 1985. Interestingly, the main infusion of index-linked bonds occurred during a period of declining inflation rates (the rate of change of consumer prices was about $5 \%$ for $1983-84$, as compared to an average rate of $10 \%$ for $1980-82$ ).

In terms of market acceptance, the indexed bonds now occupy a significant position in the British financial picture. However, there has been little trading activity in these instruments. It is reasonable to conjecture that a similar degree of market interest would greet the issue of indexed bonds by the U.S. government. In the absence of such issues, a private market in price-index futures would meet a similar purpose. Therefore, they would have some market interest but probably not a great deal of trading volume.

3. Because the index linking involves a lag of 8 months, the real yield on these bonds is not entirely certain in advance. The indexed gilts have a tax advantage over the nonindexed ones because the indexation is free of income tax, whereas the inflation component of the nominal rate is subject to tax. (All gilts are free of capital-gains tax if held for more than 1 year.) However, the differences with respect to income tax do not apply to pension funds - the major holders of gilts-because they are free of income tax.

4. The information in this section comes from Rutherford (1983), from data provided by Charles Goodhart and Geoffrey Wood, and from Buckmaster \& Moore (1985).

5. But, since the U.S. bonds are not indexed, they differ in risk characteristics from the indexed British bonds. There are also differences in tax treatment between the American and British instruments. 


\section{Consumer Price Index Futures and Real Effects from the Volatility of Inflation and Interest Rates}

A number of researchers have documented the adverse economic effects from volatility of interest rates and inflation. Evans (1984) shows that a higher volatility of interest rates is associated with a lower level of output. Specifically, he estimates the regression equation for annual data from 1947-81 (with standard errors in parentheses):

$$
\begin{aligned}
& \log (\text { real GNP })_{t}=\ldots+.43 \log (\text { real GNP })_{t-1}+1.01 D M R_{t} \\
& \text { (.10) } \\
& +.74 D M R_{t-1}+.044 \log \left(G_{t}\right)-.021 V R_{t} \text {. }
\end{aligned}
$$

This equation indicates the expansionary effect of current and lagged monetary shocks (called $D M R$ ) and of real federal purchases $(G)$. It also shows a negative effect from a higher value of a measure of interest rate volatility, $V R$. In particular, this last influence plays a major role in the recent recession-output is estimated to be $2 \%-3 \%$ below trend on average from 1980 to 1983 because of this factor.

Cukierman (1983) and Marquez and Vining (1983) surveyed the existing evidence about macroeconomic effects on the dispersions of relative prices and of beliefs about inflation. There is strong evidence from the United States and other countries that a greater volatility of overall inflation is associated with a higher variance of changes in relative prices. For example, this connection is verified for the United States by Vining and Elwertowski (1976) and Parks (1978), for Canada by Chambers and Dunn (1977), for Germany by Fischer (1981a), and for a cross section of countries by Glejser (1965). However, there is little evidence that the observed relationships derive from variability of money (Hercowitz 1982) and some suggestion that supply shocks are crucial (Fischer 1981b). Cukierman and Wachtel (1979)_by using the Livingston survey for the United States-demonstrated that (as I noted before) a greater variability of overall inflation tends also to be accompanied by a greater variance of expectations about inflation.

Other researchers find that a greater dispersion of relative prices is associated with a lower level of real economic activity. For example, Blejer and Leiderman (1980) estimate the regression equations for the United States from 1949 to 1975 (with standard errors in parentheses):

$$
\log \left(y_{t}\right)=\ldots-14.9 V_{t}, \quad U_{t}=\ldots+4.9 V_{t} .
$$

Here, $y$ is real GNP, $U$ is the unemployment rate, and $V$ is a measure of relative price dispersion. (I have omitted some other variables, such as monetary shocks, that were also included in the regressions.) Thus Blejer and Leiderman conclude that a higher value of relative price 
dispersion, $V_{t}$, means lower output, $y_{t}$, and a higher unemployment rate, $U_{t}$.

Similarly, Levi and Makin (1980) estimate the equation (1948-75 for the United States):

$$
d N_{t}=\ldots-.63 \sigma_{t},
$$

where $d N_{t}$ is the growth rate of employment, and $\sigma_{t}$ is the dispersion of inflationary expectations from the Livingston survey. Thus a greater variance of beliefs about inflation, $\sigma_{t}$, is associated with a lower growth rate of employment.

Because of the beneficial effects on the flow of information, a futures market in price indices (or a market in indexed bonds) would tend to lower the dispersion of relative prices, $V_{t}$, and, especially, to reduce the dispersion of inflationary expectations, $\sigma_{t}$. Hence, the findings reported above suggest that this improvement in information flow would also tend to raise the levels of output, investment, and employment.

Some direct evidence on the effects of futures markets on information flows comes from the study by Huberman and Schwert (1985), who consider the market for indexed bonds in Israel. The existence of an indexed bond market allows the aggregation of information about inflation in much the same manner as would a futures market in price indices. In particular, if prices perfectly aggregate the information possessed by the participants in various local markets, then, when a price index such as the CPI is announced, the price of an indexed bond should not change. This result follows because the CPI announcement contains information about inflation over the previous month-but, by hypothesis, trading during the previous month already led the indexed bond price to aggregate perfectly the information about inflation from each local market during that period. Thus the movement in indexed bond prices on the day the CPI is announced is a measure of the extent to which the market prices over the previous days did not perfectly aggregate information. Huberman and Schwert found that there was only a small effect on the prices of indexed bonds on the announcement date. Thus, with the existence of the indexed bond market, people obtained information rapidly about the overall price level. This result suggests that the existence of a market for price-index futures in the United States would have similar beneficial effects on the flow of price information.

\section{Money and Interest Rates}

A number of researchers (e.g., Cornell 1983a, 1983b; Roley and Walsh 1983) suggest that the shift in the behavior of monetary policy in the fall of 1979-supposedly to pay more attention to monetary aggregates and less to interest rates-may partially explain the higher volatility of 
TABLE 5 Estimated Response (in Basis Points) to a $1 \%$ Surprise in Money

\begin{tabular}{lcc}
\hline Yield on: & September 1977 -October 1979 & October 1979-82 \\
\hline 3-month Treasury bills & 6.5 & 36.4 \\
& $(3.1)$ & $(6.0)$ \\
1-year bonds & 5.2 & 35.5 \\
& $(1.8)$ & $(4.7)$ \\
5-year bonds & 2.6 & 21.2 \\
& $(.9)$ & $(3.3)$ \\
20-year bonds & 1.2 & 14.4 \\
& $(.7)$ & $(2.8)$ \\
\hline
\end{tabular}

SourCE.-Based on Roley and Walsh (1983, table 1).

NotE.-Standard errors of coefficients appear in parentheses.

interest rates in recent years. The data show that, in the period from late 1979 until late 1982, nominal yields on bonds responded strongly to the Federal Reserve's announcement that M1 was higher than anticipated. Here the anticipations on M1 are the values recorded in a survey of financial market participants by Money Market Services, Inc. The nature of the evidence shows up in table 5. For weekly data from the period October 1979-October 1982, the estimate is that a $1 \%$ surprise increase in M1 (currently about $\$ 5$ billion, which would be a large but not unprecedented movement) raised yields on 3-month Treasury bills by about 36 basis points. The effect is positive on yields for bonds of all maturities but declines to about 14 basis points on 20-year government bonds. On the other hand, for the earlier period September 1977October 1979-before the change in the Federal Reserve's operating procedures-the effects were much smaller, amounting to 6 basis points for 3-month Treasury bills and 1 basis point for 20-year bonds.

In some recent research on the weekly data from fall 1979 to fall 1982, I find that, in addition to the effect from M1 announcements, yields on Treasury bills and 20-year government bonds respond inversely to the movements in the monetary base from the previous 2 weeks. Thus there is apparently a short-lived "liquidity effect" from changes in high-powered money. These results may be consistent with the transactions-based monetary theory in Grossman and Weiss (1983) and Rotemberg (1984). Further, in the more recent data for 1983, the effect of money announcements on interest rates has weakened. This observation may be associated with another shift of monetary policy, this time away from the targeting of monetary aggregates. In any event, this behavior goes along with a reduction in the volatility of interest rates for 1983-84.

\section{Criticisms of Futures Markets}

One common objection to futures and options markets-which might apply as a particular case to price-index futures-is that these activities draw capital away from "productive enterprises." (Similar attacks 
have been made against corporate mergers.) Of course, there is no direct effect of futures/options trading on the aggregate of available credit. That is, these markets do not involve a net position, long or short, in assets. Rather, there would have to be indirect effects on the allocation of resources across sectors, or on the overall desire to save, or on the aggregate demand for investment, and so on.

To the extent that organized futures trading provides a convenient vehicle for hedging or sharpens the available price signals, there would be beneficial real effects on economic activity. The possibility to lay off risks-notably, those from inflation-would spur investment demand. Also, there would be a general channeling of activity toward the most productive areas rather than toward those that happened to entail low inflation risk or that had rapid payoffs, and so on. Corresponding to the economic gains, there would be some real resources used up in the process of organizing futures markets and in the time spent by traders. But through the usual functioning of the private economy, the amounts of these efforts would be related to the social product of the activity. That is, economically inefficient ("excessive") trading activity tends not to have survival value. ${ }^{6}$ If anything, the tendency is for organizers of markets to be unable to capture the full social returns from their activities. For example, as stressed by Grossman (1977), people can free ride on the valuable price information that is generated by futures markets. Hence the number of organized markets-and specifically the varieties of futures contracts available-tends to be fewer than is socially optimal.

Another frequent criticism is that futures markets have themselves led to volatility in the prices of the underlying goods or, more recently, of interest rates, stock prices, and so on. However, in a direct test for six commodities, Cox (1976) finds evidence that the introduction of a futures market lowers the variability of spot prices. Telser and Higinbotham (1977), Telser (1981), and Carlton (1984) do note the positive association between price uncertainty and the overall volume of futures trading. ${ }^{7}$ But the causation is in the opposite direction-that is, an increase in price volatility, as in the period since the mid-1970s, leads to an expansion in the number of futures markets and in the amount of trading. Similarly, the relatively tranquil period of the 1950 s and 1960s saw a decrease in activity on futures markets. Futures trading should get substantial credit neither for this time of tranquility nor for the price volatility of recent years.

6. The presence of speculators who may like gambling does not alter the argument. First, the utility gained from gambling is as good as any other type of utility. Second, as discussed in Telser (1981, pp. 9 ff.), the existence of these speculators tends to lower the average price paid by others.

7. Carlton shows also that government regulation has an important independent effect on the number of futures markets and on trading volume. 


\section{References}

Blejer, M., and Leiderman, L. 1980. On the real effects of inflation and relative price variability: Some empirical evidence. Review of Economics and Statistics 62, no. 4 (November): 539-44.

Board of Governors. Federal Reserve System. 1981. Annual Statistical Supplement. Washington, D.C.: U.S. Government Printing Office.

Bodie, Z.; Kane, A.; and McDonald, R. 1983. Why are real interest rates so high? NBER Working Paper no. 1141. Cambridge, Mass.: NBER, June.

Buckmaster \& Moore. 1985. Index-linked Gilt Book. London: Buckmaster \& Moore.

Carlton, D. W. 1984. Futures markets: Their purpose, their history, their growth, their successes and failures. Journal of Futures Markets 4 (Fall): 237-71.

Chambers, E., and Dunn. J. 1977. New Canadian evidence on relative price behavior since 1950. Paper presented at the meetings of the Canadian Economic Association.

Cornell, B. 1983a. Money supply announcements and interest rates: Another view. Journal of Business 56, no. 1 (January): 1-23.

Cornell, B. $1983 b$. The money supply announcements puzzle. American Economic Review 73, no. 4 (September): 644-57.

Cox, C. 1976. Futures trading and market information. Journal of Political Economy 84, no. 6 (December): 1215-37.

Cukierman, A. 1983. Relative price variability and inflation: A survey and further results. Carnegie-Rochester Conference Series on Public Policy 19 (Autumn): 103-57.

Cukierman, A., and Wachtel, P. 1979. Differential inflationary expectations and the variability of the rate of inflation: Theory and evidence. American Economic Review 69, no. 4 (September): 595-609.

Evans, P. 1984. The effects on output of money growth and interest rate volatility in the United States. Journal of Political Economy 92, no. 2 (April): 204-22.

Fair, R. 1979. An analysis of the accuracy of four macroeconometric models. Journal of Political Economy 87, no. 4 (August): 701-18.

Fama, E. 1975. Short-term interest rates as predictors of inflation. American Economic Review 65, no. 3 (June): 269-82.

Fama, E., and Gibbons, M. 1982. Inflation, real returns, and capital investment. Journal of Monetary Economics 9, no. 3 (May): 297-323

Fischer, S. 1981a. Relative price variability and inflation in the United States and Germany. NBER Conference Paper no. 129. Cambridge, Mass.: NBER, November.

Fischer, S. $1981 b$. Relative shocks, relative price variability, and inflation. Brookings Papers on Economic Activity, no. 2, pp. 381-431.

Friedman, M. 1977. Nobel lecture: Inflation and unemployment. Journal of Political Economy 85, no. 3 (June): 451-72.

Friedman, M., and Friedman, R. 1984. Tyranny of the Status Quo. San Diego, Calif.: Harcourt Brace.

Glejser, H. 1965. Inflation, productivity, and relative prices-statistical study. Review of Economics and Statistics 47, no. 1 (February): 76-80.

Grossman, S. 1977. The existence of futures markets, noisy rational expectations, and informational externalities. Review of Economic Studies 44, no. 138 (October): 43149.

Grossman, S., and Weiss, L. 1983. A transactions-based model of the monetary transmission mechanism. American Economic Review 73, no. 5 (December): 871-80.

Hercowitz, Z. 1982. Money and price dispersion in the United States. Journal of Monetary Economics 10, no. 1 (July): 25-37.

Huberman, G., and Schwert, G. W. 1985. Information aggregation, inflation, and the pricing of indexed bonds. Journal of Political Economy 93, no. 1 (February): 92-114.

Ibbotson, R., and Sinquefield, R. 1985. Stocks, Bonds, Bills and Inflation: 1985 Yearbook. Chicago: Ibbotson Associates.

Levi, M., and Makin, J. 1980. Inflation uncertainty and the Phillips curve: Some empirical evidence. American Economic Review 70, no. 5 (December): 1022-27.

Marquez, J., and Vining, D. 1983. Inflation and relative price behavior: A survey of the literature. In M. Ballabon (ed.), Economic Perspectives. New York: Harwood Academic Publishers. 
Michael, R. 1979. Variation across households in the rate of inflation. Journal of Money, Credit and Banking 11, no. 1 (February): 32-46.

Page, S. A. B., and Trollope, S. 1974. An international survey of indexing and its effects. National Institute Economic Review 70 (November): 46-60.

Parks, R. 1978. Inflation and relative price variability. Journal of Political Economy 86, no. 1 (February): 79-95.

Roley, V., and Walsh, C. 1983. Monetary policy regimes, expected inflation, and the response of interest rates to money announcements. NBER Working Paper no. 1181. Cambridge, Mass.: NBER, August.

Rotemberg, J. J. 1984. A monetary equilibrium model with transactions cost. Journal of Political Economy 92, no. 1 (February): 40-58.

Rutherford, J. 1983. Index-linked gilts. National Westminster Bank Quarterly Review (November): 2-17.

Schwert, G. W., and Nelson, C. 1977. Short-term interest rates as predictors of inflation: On testing the hypothesis that the real rate of interest is constant. American Economic Review 67, no. 3 (June): 478-86.

Telser, L. G. 1981. Why there are organized futures markets. Journal of Law and Economics 24, no. 1 (April): 1-22.

Telser, L. G., and Higinbotham, H. 1977. Organized futures markets: Costs and benefits. Journal of Political Economy 85, no. 5 (October): 969-1000.

Vining, D., and Elwertowski, T. 1976. The relationship between relative prices and the general price level. American Economic Review 66, no. 4 (September): 699-708. 